\title{
PENINGKATAN PENDAPATAN MASYARAKAT DESA BEGINJAN, KABUPATEN SANGGAU MELALUI PENGOLAHAN PRODUK IKAN ASLI KALIMANTAN
}

\author{
Widadi Padmarsari Soetignya $^{1^{*}}$, Wahyu Laksana ${ }^{2}$ Ahmad Mulyadi Sirojul Munir ${ }^{3}$ \\ 1,3) Jurusan Budidaya Pertanian, FakultasPertanian, Universitas Tanjungpura, \\ ${ }^{2}$ Jurusan Manajemen, Fakultas Ekonomi, Universitas Tanjungpura, \\ ${ }^{1)}$ fx.widadi.padmarsari.s@faperta.untan.ac.id ${ }^{2)}$ wahyulaksana1959@gmail.com ${ }^{3)}$ ahmadm@yahoo.om
}

\begin{abstract}
Abstrak
Potensi ikan air tawar di Desa Beginjan, Kecamatan Tayan Hilir, Kabupaten sangat tinggi. Sumberdaya ikan air tawar tersebut memberikan manfaat ekonomi bagi masyarakat Desa Beginjan. Namun demikian, harga ikan akan menurun apabila jumlah tangkapan melimpah. Kegiatan Program Kemitraan Masyarakat (PKM) ini bertujuan untuk meningkatkan pendapatan masyarakat khususnya kelompok pengolah ikan di Desa Beginjan, Kecamatan Tayan Hilir, Kabupaten Sanggau melalui pengolahan produk ikan asli Kalimantan dalam bentuk kerupuk dan bakso ikan. Jenis ikan yang dipergunakan adalah ikan toman ( Channa micropeltes) dan ikan baung (Hemibagrus nemurus) yang merupakan hasil tangkapan nelayan setempat. Metode yang digunakan pada kegiatan PKM ini adalah dengan cara ceramah, pelatihan yang meliputi pengolahan bakso dan kerupuk ikan, pengemasan produk olahan ikan, dan manajemen usaha, serta pendapingan usaha. Hasil kegiatan PKM ini menunjukkan bahwa kelompok mitra sudah mampu melakukan pengolahan ikan menjadi bakso dan kerupuk ikan. Mitra juga sudah mampu mengemas dan memasarkan hasil olahan tersebut dalam skala lokal. Pengolahan dalam bentuk bakso dan kerupuk ikan dapat meningkatkan keuntungan daripada dijual bebas dengan besar keuntungan yang bervariasi tergantung harga ikan yang bersifat musiman.
\end{abstract}

Keywords: bakso ikan, baung, kerupuk ikan, toman

\begin{abstract}
The potency of indigenous freshwater fish in Beginjan village is very high. The freshwater fish give economic value for community in Beginjan Villaege. But the price of the fish drops when the fish catch increases. Diversification of fish food processing as a community engagement activity helps to improve economic offish food process in Beginjan Village, Tayan Hilir District, Sanggau Regency. This activity consist mainly in teaching how to process fish balls and fish crackers, packing of fish food products, but also finance and business management. Fish food products used toman (Channa micropeltes) and baung fish (Hemibagrus nemurus). The results of this activity indicated that the partner group have been able to do fish food processing into fish balls and fish crackers. Partners also have been able to package and market the processed products within the local scope. Fish food processing into fish ball and fish cracker could increase the profit more than just by selling fresh fish
\end{abstract}

Keywords: Fish balls, fish crackers,toman,baung 


\section{PENDAHULUAN}

Desa Beginjan merupakan salah satu desa yang secara administratif termasuk ke dalam Kecamatan Tayan Hilir, Kabupaten Sanggau. Desa ini terdiri atas lima dusun yaitu yaitu Dusun Pandu, Dusun Beginjan, Dusun Perupuk, Dusun Sungai Ronggas, dan Dusun Durian Baru. Berdasarkan profil Desa Beginjan, luas wilayahnya sebesar 4.995 hektar dengan jumlah penduduk laki laki sebanyak 993 orang dan perempuan sebanyak 896 orang yang tergabung dalam KK berjumlah 549. Desa ini terletak berdekatan dengan beberapa perusahaan yang bergerak di sektor perkebunan kelapa sawit dan pertambangan seperti Antam Tbk yang bergerak di pertambangan bauksit. Oleh karena itu, sebagian penduduknya yang memenuhi kualifikasi pendidikan yang diperlukan perusahaan bekerja sebagai karyawan di perusahaan tersebut, sedangkan yang lainnya bekerja sebagai petani dan pedagang.

Selain pertambangan dan pertanian, Desa Beginjan juga memiliki potensi di sektor perikanan. Hal ini disebabkan letaknya yang berada di tepi Sungai Kapuas dan juga berdekatan dengan beberapa danau yaitu Danau Bekat dan Danau Kelubi. Kedua danau merupakan ekosistem air hitam yang tinggi genangan airnya dipengaruhi oleh curah hujan. Potensi ikan yang beragam memberikan efek positif bagi sebagian masyarakat di sekitarnya dengan memanfaatkannya untuk mencari ikan. Umumnya kegiatan mencari ikan tersebut bukanlah pekerjaan utama, tetapi hanyalah pekerjaan sampingan bagi masyarakat di Desa Beginjan. Berdasarkan pengamatan di lapangan dan wawancara terhadap nelayan, terdapat beberapa jenis ikan asli (indigenou) yang dominan antara lain Channa micropeltes (toman), C. maruloides (kerandang),
Osteochilus melanopleura (kelabau), Hemibagrus nemurus (baung), dan Helastoma temmincki (biawan) dan di antara ikan tersebut beberapa jenis ikan hanya melimpah di musim tertentu yaitu musim kemarau seperti ikan biawan. Pada saat ikan ini melimpah, maka harga jual ikan-ikan tersebut akan mengalami penurunan.

Ikan dan produk olahannya berperan penting sebagai sumber nutrisi bagi manusia yaitu sumber protein, asam lemak,vitamin dan unsur-unsur mikro lainnya (Belitz et al., 2009). Besarnya manfaat dari ikan dan produk olahannya juga dirasakan oleh masyarakat di Desa Beginjan. Potensi sumberdaya ikan di Desa Beginjan memberikan manfaat secara ekonomi dalam bentuk ikan segar dan sebagian diolah menjadi ikan ikan asin ketika tangkapan ikan melimpah. Proses pengolahan ikan asin dilakukan oleh sebagian ibu rumah tangga secara mandiri dan sebagian tergabung dalam dua kelompok pengolah ikan "Mina Makmur" dan "Maju Mandiri". Produksi ikan asin tersebut masih dilakukan dalam skala rumah tangga dan dipasarkan pada pengepul untuk dijual di Pasar Tayan. Jumlah omzet dan keuntungannya secara pasti belum terdata karena belum ada manajemen yang tertata baik. Namun berdasarkan wawancara terhadap beberapa pengolah ikan, jumlah produksi ikan asin pada musim ikan melimpah diestimasikan sebanyak 10-20 kg/hari/ pengolah ikan.

Mitra kegiatan Program Kemitraan Masyarakat (PKM) ini adalah Kelompok Pengolah Ikan di Desa Beginjan Kecamatan Tayan Hilir Kabupaten Sanggau yaitu Mina Makmur dan Maju Mandiri. Kedua kelompok aktif dalam usaha pengolahan ikan segar menjadi ikan asin. Hasil observasi lapangan dan wawancara menunjukkan usaha pengolahan ikan tersebut menghasilkan keuntungan yang lebih besar dibandingkan 
jika ikan tersebut dijual segar, namun demikian, rata-rata tingkat pendapatan yang diperoleh kedua kelompok tersebut masih rendah. Ada dua aspek permasalahan yang dihadapi kedua mitra yaitu produksi dan manajemen. Untuk aspek produksi, ada dua permasalahan utama yang berkaitan dengan penanganan olahan ikan yaitu jenis produk olahan ikan yang kurang beragam, dan penanganan terhadap produk olahan yang sudah dihasilkan masih konvensional, belum dilakukan pengemasan dan pelabelan produk yang baik serta tidak memiliki legalitas keamanan produknya. Sedangkan permasalahan pada aspek manajemen adalah terbatasnya pengetahuan tentang manajemen keuangan, produksi dan pemasaran yang berpengaruh pada mutu produk olahan ikan yang dihasilkan belum seragam, kontinuitas belum dapat terpenuhi dan jangkauan pemasaran masih terbatas.

Berdasarkan permasalahan di atas, maka ada beberapa solusi yang ditawarkan pada kegiatan PKM ini. Berkaitan dengan permasalahan pada aspek produksi yaitu kurang beragamnya produk olahan ikan yang dihasilkan, maka solusi yang ditawarkan adalah diversifikasi produk olahan ikan. Menurut Wardani et al. (2010), produk olahan ikan memberikan gambaran yang lebih menguntungkan daripada produk ikan segar seperti adanya berbagai variasi bentuk dan ukuran produk, jumlah produk sedikit dan menghemat tempat, produk umumnya tahan lama dan jenis olahan selalu sama sesuai permintaan.

Pada kegiatan ini produk olahan ikan yang dipilih untuk diintroduksikan kepada mitra PKM adalah kerupuk dan bakso ikan dengan bahan baku ikan asli Kalimantan yang banyak ditangkap nelayan dari Danau Bekat dan Danau Kelubi yang berada di sekitar Desa Beginjan. Ada beberapa pertimbangan pemilihan kerupuk sebagai solusi produk yang ditawarkan yaitu:

1. Kerupuk ikan sudah dikenal oleh orang banyak, meskipun umumnya orang mengenal bahan baku kerupuk ikan adalah ikan laut seperti ikan tengiri.

2. Pengolahannya sangat mudah, sehingga dapat dipahami dan dilakukan oleh masyarakat dengan tingkat pendidikan rendah.

3. Modal pengolahannya tidak besar dan bahan pembuatannya juga mudah diperoleh

4. Produk olahan yang tahan lama (Ernawati \& Wulandari, 2013).

Beberapa penelitian menunjukkan bahwa kerupuk ikan dapat dibuat dari ikan air tawar seperti ikan nila, lele dan kelompok jenis ikan gabus. Pengolahan kerupuk berbahan baku ikan gabus pernah dilakukan dalam skala laboratorium, namun belum dilakukan dengan tujuan komersial (Setiawan et al., 2013). Dengan pertimbangan kandungan albumin yang tinggi pada golongan ikan gabus ( Channa spp) diantaranya Channa striata (gabus), dan C. micropeltes (toman), yang banyak terdapat di Danau Bekat dan Kelubi diyakini produk kerupuk ini menjadi khas dan memiliki prospek pemasaran yang tinggi.

Bentuk olahan lainnya sebagai solusi yang ditawarkan adalah bakso ikan. Bakso merupakan produk makanan berbentuk bulat yang diperoleh dari campuran daging dan pati atau serealia dengan penambahan zat makanan yang diijinkan (Purnomo \& Rahardian, 2008). Umumnya, masyarakat di Desa Beginjan mengenal bakso yang berbahan baku daging sapi. Produk bakso ikan diyakini juga dapat menjadi alternatif produk olahan ikan karena proses pengolahannya dan cara perolehan bahan bakunya mudah. 
adalah:

Tujuan dari kegiatan PKM ini

1. Menghasilkan diversifikasi produk olahan ikan berupa kerupuk dan bakso ikan berbahan baku ikan asli Kalimantan.

2. Meningkatkan pengetahuan dan ketrampilan dari mitra PKM tentang pembuatan desain kemasan, pelabelan dan perijinan produk PIRT serta manajemen adminitrasi keuangan, analisis usaha sederhana, strategi produksi dan pemasaran serta menggunakan alat promosi seperti leaflet/brosur.

3. Meningkatkan pendapatan penduduk Desa Beginjan khususnya kelompok pengolah ikan Mina Makmur dan Maju Mandiri

\section{METODE PELAKSANAAN}

Kegiatan PKM ini dilakukan terdiri dari beberapa tahap kegiatan yaitu: tahap orientasi dan sosialisasi, tahap pelatihan, tahap pendampingan, dan tahap evaluasi dan monitoring. Selanjutnya pelaksanaan kegiatan PKM ini dilakukan dengan beberapa metode yaitu:

\section{Ceramah atau penyuluhan}

Metode ceramah atau penyuluhan dilakukan pada saat tahap sosialisasi dan tahap pelatihan. Pada tahap sosialisasi materi ceramah yang di-berikan adalah tentang diversifikasi produk olahan ikan. Sedangkan pada tahap pelatihan yang berlangsung dalam dua subtahapan, materi yang disampaikan adalah pada sub tahap I tentang prinsip-prinsip dasar proses pengolahan bakso dan kerupuk ikan dan juga nilai tambah yang dihasilkannya. Materi yang disampai-kan pada subtahap II adalah kegiatan pasca produksi yaitu pengemasan, pelabelan, perijinan produk untuk dipasarkan dan aspek manajemen usaha.

\section{Demonstrasi atau peragaan}

Demonstrasi atau peragaan adalah salah satu metode penyuluhan yang berdasarkan pada pendekatan kelompok. Mitra PKM bekerja sama dibimbing dan diarahkan secara kelompok untuk melakukan suatu kegiatan yang lebih produktif. Dalam kegiatan PKM ini, metode peragaan dibagi ke dalam dua jenis yaitu peragaan cara dan peragaan hasil. Peragaan cara dilakukan dengan menunjukkan secara jelas dan nyata tentang cara atau tahap-tahap pada pengolahan kerupuk dan bakso ikan. Tujuannya adalah untuk memberi keyakinan peserta tentang cara kerja proses pengolahan bakso dan kerupuk ikan tersebut mudah dilaku-kan. Peragaan cara juga dilakukan utuk pengemasan, dan pelabelan. Jenis peragaan yang kedua adalah peragaan hasil yang bertujuan untuk menunjukkan secara nyata dari hasil proses pengolahan bakso dan kerupuk ikan.

\section{Pelatihan}

Pelatihan atau praktek langsung pada kegiatan PKM ini dilakukan dalam dua subtahapan yaitu subtahap I adalah pelatihan pengolahan bakso dan kerupuk ikan, sedangkan subtahap II adalah praktek langsung kegiatan pasca produksi dan manajemen usaha. Kegiatan pasca produksi tersebut meliputi pengemasan, pelabelan, dan perijinan produksi. Pada subtahap I dipraktek-kan proses pengolahan bakso dan kerupuk ikan berbahan baku ikan toman dan baung. Pada subtahap II dipraktekkan secara langsung kegiat-an pengemasan dan pelabelan dari mulai penggunaan berbagai alat kemasan, cara membuat desain dan pelabelan kemasan. Pengemasan produk olahan ikan yang diintroduksi pada kegiatan PKM ini adalah dengan cara vaccum pressure, dan plastik sealer dengan dilengkapi desain produk kemasan yang menarik 
dan informatif. Pelatihan untuk aspek manajemen terdiri dari manajemen adminsitrasi keuangan, perencanaan produksi dari peng-hitungan dan penyedia-an bahan baku sampai waktu proses produksi, pem-buatan leaflet atau brosur serta penataan layout dari produk olahan ikan yang dihasilkan. Secara detail gambaran tentang proses pengolahan bakso dan kerupuk dijelaskan dalam uraian berikut ini:

1. Bakso Ikan

Berbeda dengan daging sapi, daging ikan mempunyai lebih sedikit jaringan ikat serta tidak mengandung lebih banyak air di-bandingkan dengan daging sapi. Menurut Purnomo et al. (2013); Harioedojo et al., (2015), kadar air dalam ikan cukup tinggi, yaitu antara $60 \%$ sampai dengan $80 \%$ dan hal ini berakibat jika pen-campuran daging ikan semakin tinggi, maka semakin meningkat pula kadar air dalam bakso dan berpengaruh pada tekstur bakso yang dihasilkan menjadi lembek. Untuk meningkatkan kekenyalan dari bakso ikan dapat ditambahkan beberapa bahan pengemulsi di antaranya STPP dan karaginan. Nurhoda et al. (2017) menyatakan penambahan karaginan sebanyak $1 \%$ memberikan hasil bakso yang paling disukai. Pada kegiatan PKM ini, untuk meningkatkan kekenyalan bakso ikan toman dan baung yang akan diintroduksi, dalam proses pengolahannya ditambahkan es batu dan STPP sebanyak 1\%. Secara garis besar, proses pengolahan bakso ikan berbahan dasar ikan toman dan baung yang dalam kegiatan PKM ini merupakan modifikasi dari pengolahan bakso ikan (Riyadi \& Atmaka, 2010) dan dilakukan sebagai berikut:

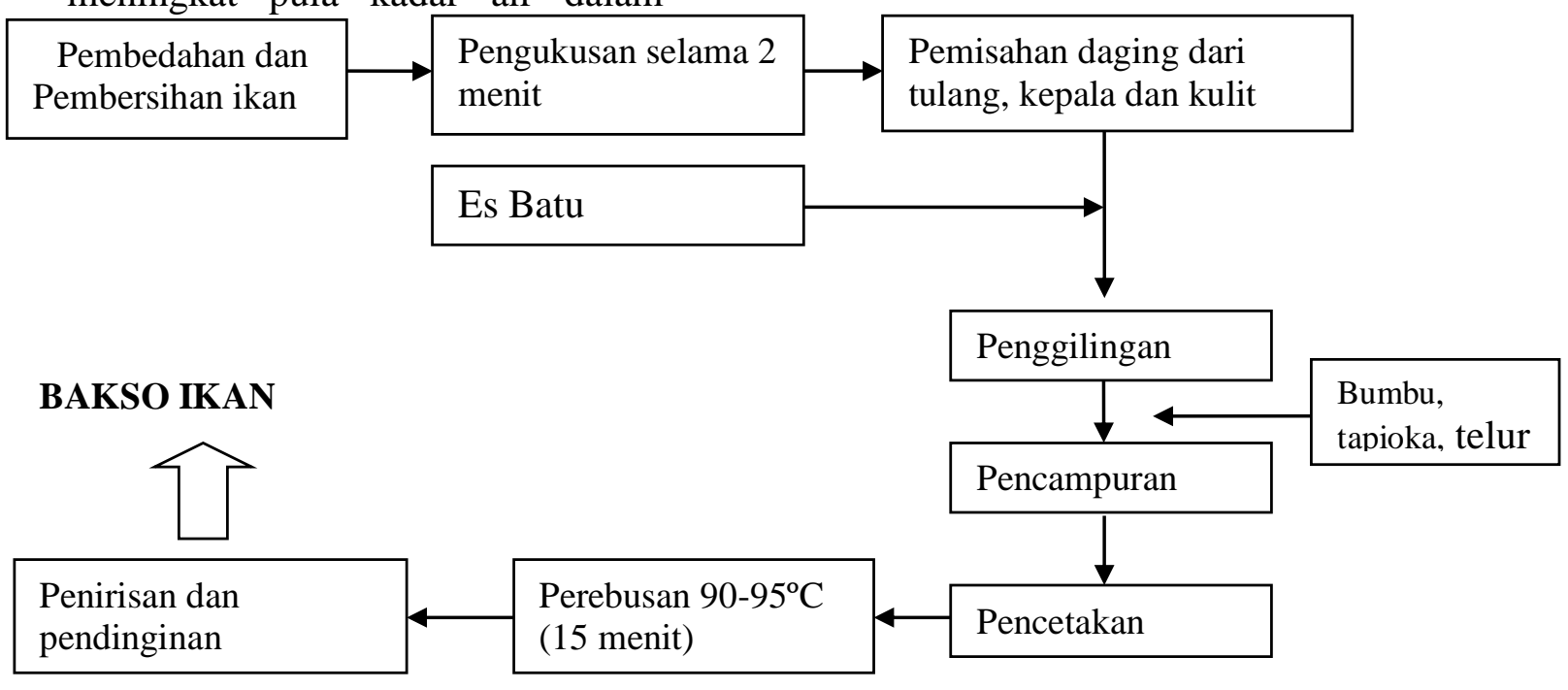

Gambar 1. Diagram pengolahan bakso ikan

2. Kerupuk Ikan

Kerupuk merupakan jenis makanan kering yang terbuat dari bahan-bahan yang mengandung pati cukup tinggi. Dalam pelatihan ini, ikan yang digunakan sebagai bahan dasar pengolahan kerupuk adalah ikan toman dan baung. Ikan-ikan ini banyak terdapat di ekosistem air hitam termasuk Danau Bekat dan Kelubi. Ikan toman termasuk kelompok ikan gabus yang memiliki protein cukup tinggi dengan kandungan albumin yang tinggi pula. 
Berbagai modifikasi dalam proses pengolahan kerupuk ikan gabus juga telah dilakukan termasuk bahan substitusi campuran tepung yang biasanya menggunakan tepung tapioka atau juga tepung terigu dapat digantikan dengan tepung lainnya seperti tepung sagu. Menurut Laiya et al (2014), bertambahnya konsentrasi daging ikan gabus menyebabkan kenampakan kerupuk ikan gabus yang dihasilkan memiliki permukaan utuh, rapih dan ketebalan kurang rata. Pada kegiatan PKM ini, proses pengolahan kerupuk ikan yang akan diintroduksi dilakukan dengan cara sebagai berikut:

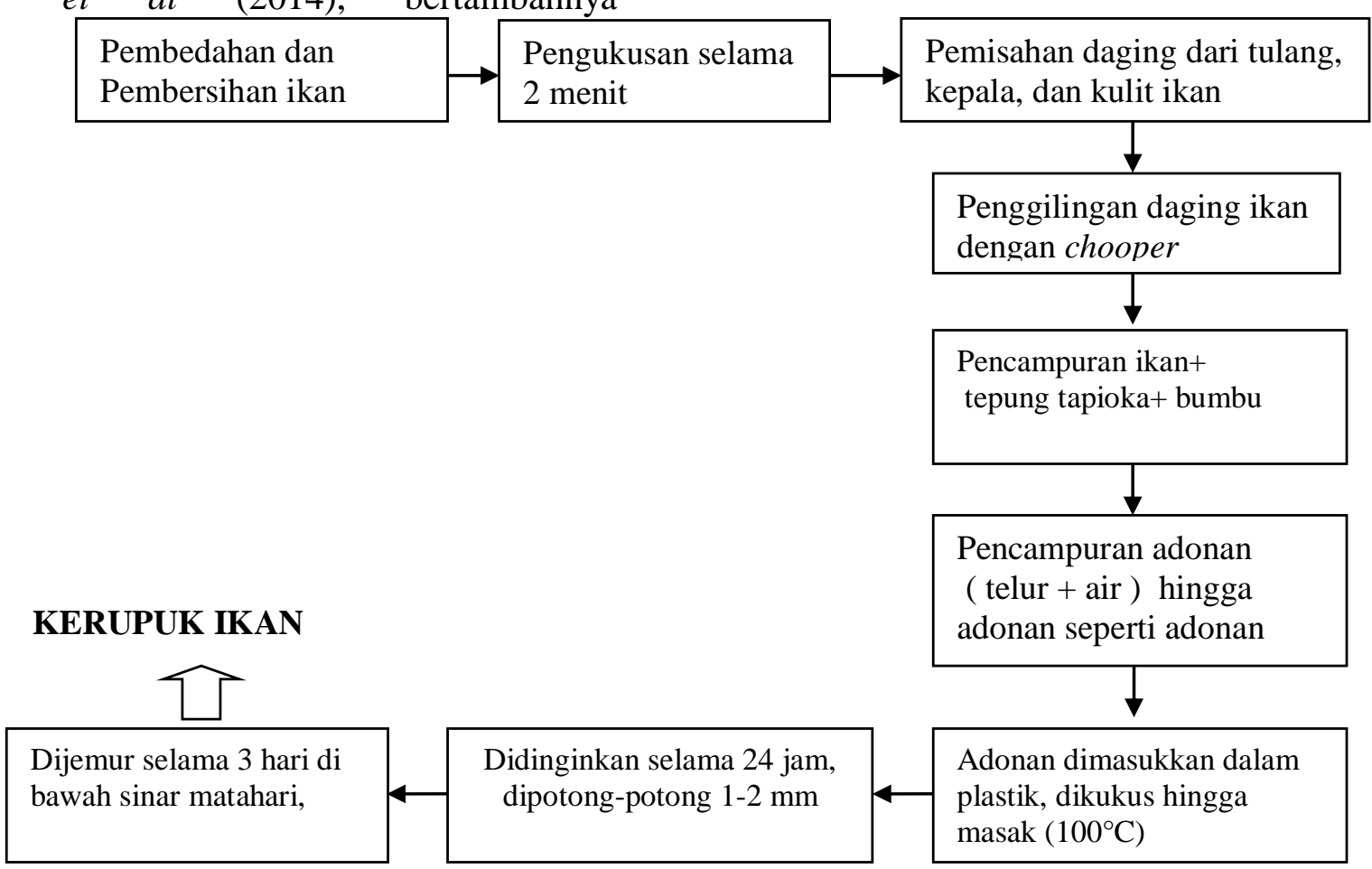

Gambar 2. Diagram proses pengolahan kerupuk ikan4.Pendampingan

Kegiatan pendampingan dilakukan dengan cara mengunjungi lokasi mitra PKM, berdiskusi dan mempraktekkan kembali untuk materi yang hasilnya masih belum benar-benar dikuasai pada pelatihan sebelumnya. Apabila terdapat pertanyaan dan keluhan mengenai pengolahan bakso dan kerupuk ikan maka akan diusahakan diberikan solusi terkait dengan permasalahan tersebut.

\section{Evaluasi dan monitoring}

Evaluasi dilakukan pada setiap akhir kegiatan dan juga secara menyeluruh. Proses evaluasi dilakukan dengan kuisioner, wawancara dan observasi. Evaluasi dan monitoring pada setiap kegiatan pelatihan dilakukan dengan tujuan untuk mengetahui tingkat keberhasilan mitra PKM dalam menyerap materi pelatihan. Evaluasi program secara menyeluruh dilakukan untuk memberikan solusi terhadap permasalahan yang mungkin muncul selama program berlangsung dan kesiapan kedua produsen produk bakso dan kerupuk setelah program kemitraan masyarakat (PKM) berakhir.

\section{HASIL DAN PEMBAHASAN}

\section{Orientasi dan Sosialisasi}

Program kemitraan Masyarakat berupa diversifikasi olahan ikan dalam bentuk bakso dan kerupuk ikan dimulai dengan kegiatan orientasi dan sosialisasi. 
Pada saat orientasi ini sekaligus dilakukan untuk perijinan kegiatan dengan pelaporan kepada Kepala Desa Beginjan. Meskipun sasaran kegiatan PKM ini adalah kelompok pengolah ikan, namun sosialisasi kegiatan tidak hanya ditujukan kepada anggota kelompok pengolah ikan, tetapi juga melibatkan perangkat desa, kepala dusun, perwakilan kelompok PKK dan perwakilan karang taruna. Hal ini bertujuan agar kegiatan yang akan PKM yang dilakukan dapat diketahui masyarakat Desa Beginjan, sehingga tidak terjadi kesalahpahaman antar warga dengan kelompok pengolah ikan ataupun warga dengan tim pelaksana. Dalam kegiatan sosialisasi ini disampaikan beberapa informasi termasuk tujuan kegiatan, target luaran kegiatan dan penentuan rencana jadwal kegiatan untuk tahapan-tahapan selanjutnya serta tempat pelaksanaan kegiatan pelatihan. Penentuan rencana jadwal kegiatan dilakukan dengan melibatkan mitra PKM agar mendapat saran dan umpan balik serta dapat terbangun komunikasi yang baik. Pada kesempatan sosialiasi tersebut juga disampaikan penyuluhan tentang diversifikasi produk olahan ikan yang terdiri dari beberapa materi yaitu keuntungan proses diversifikasi olahan ikan, jenis-jenis produk olahan dan pertimbangan pemilihan produk bakso dan kerupuk ikan sebagai teknologi yang akan diintroduksi kepada mitra PKM.

Hasil dari kegiatan sosialisasi ini adalah mitra PKM siap untuk terlibat aktif dalam kegiatan PKM ini. Adanya komitmen penuh dari mitra tersebut didasari pada pengkayaan materi yang telah mereka peroleh dari kegiatan sosialisasi tentang pentingnya dan kelebihan dari proses diversifikasi olahan ikan. Secara keseluruhan, peserta sosialisasi baik itu mitra PKM yaitu kelompok pengolah ikan di Desa Beginjan dan juga peserta lainnya dari

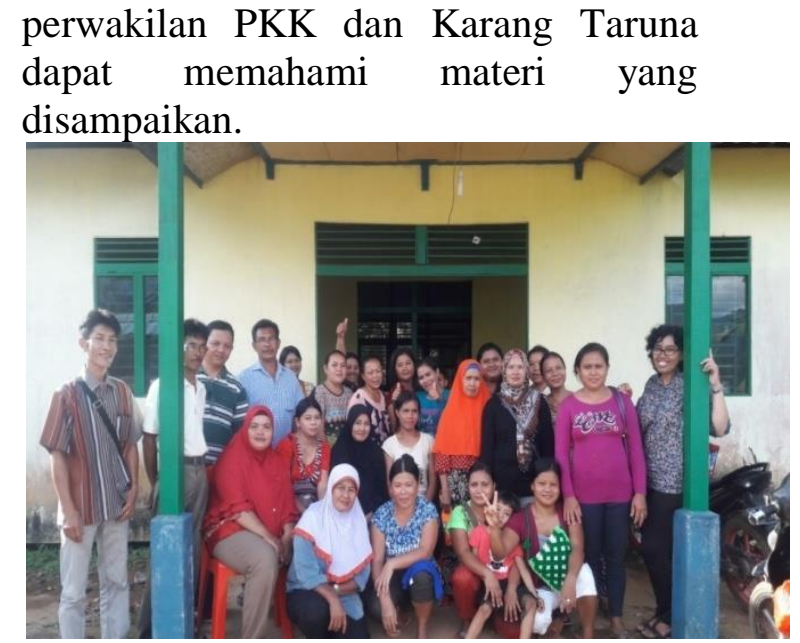

Gambar 3. Peserta sosialisasi Kegiatan PKM di Desa Beginjan

\section{Pelatihan}

Kegiatan pelatihan dihadiri oleh 20 peserta yang merupakan anggota kelompok ikan Mina Makmur dan Maju Mandiri dan sebagai tambahan peserta juga dihadiri oleh perwakilan perangkat desa. Pelatihan dilakukan dalam dua tahap yaitu tahap I adalah pelatihan pengolahan kerupuk dan bakso ikan; sedangkan tahap II adalah tahap pasca produksi dan manajemen usaha. Pelatihan tahap pasca produksi terdiri dari pengemasan, pelabelan dan ijin produksi. Pada setiap pelatihan diawali dengan ceramah, demonstrasi, praktek langsung dan evaluasi kegiatan.

Pelatihan pada tahap I diawali dengan ceramah atau penyuluhan tentang diversifikasi pengolahan ikan dalam bentuk bakso dan kerupuk ikan berkaitan dengan prinsip-prinsip dasar pengolahannya dan nilai tambah yang dihasilkan jika diolah menjadi kerupuk dan bakso ikan. Pada tahapan kegiatan ceramah ini peserta terlihat aktif yang ditunjukkan dengan beberapa pertanyaan dari peserta. Pertanyaan itu antara lain:

1. Jenis ikan yang digunakan untuk pembuatan kerupuk ikan dan bakso ikan

2. Berapa lama proses penjemuran kerupuk, sehingga mendapatkan 
produk kerupuk yang dapat mengembang dengan baik

3. Bagaimana cara mendapatkan bakso ikan yang kenyal

4. Berapa lama daya simpan produk bakso dan kerupuk ikan

5. Bagaimana cara memasarkan produk sementara produk bakso dan kerupuk ikan yang berbahan baku ikan toman dan baung masih belum banyak dikenal masyarakat

Setelah kegiatan penyuluhan dilanjutkan dengan peragaan dan praktek pengolahan kerupuk dan bakso ikan dengan menggunakan bahan utama ikan toman dan ikan baung. Pada saat peragaan dijelaskan tahapan proses dan hal-hal yang penting pada proses pengolahan bakso dan kerupuk ikan. Selesai peragaan dilanjutkan dengan praktek langsung oleh peserta untuk pengolahan kerupuk dan bakso ikan. Pelaksanaan praktek langsung pengolahan bakso dan kerupuk ikan dilakukan dengan membagi menjadi 2 kelompok di mana masing-masing kelompok diwajibkan untuk membuat masing-masing produk olahan bakso dan kerupuk ikan. Pelatihan diakhiri dengan evaluasi kegiatan yang dilakukan dengan metode observasi, dan pengisian kuisioner. Responden dipilih secara acak masing-masing kelompok 5 orang, jadi total responden sebanyak 10 orang.

Hasil evaluasi pada pelatihan tahap I menunjukkan mitra PKM mampu melakukan materi pelatihan yaitu pengolahan kerupuk dan bakso ikan berbahan baku ikan toman dan baung. Namun demikian, ada beberapa kekurangan dari hasil praktek kedua produk yaitu pada pengolahan bakso ikan, produk bakso yang dihasilkan bentuk dan ukurannya tidak seragam dan juga tekstur bakso kurang kenyal, sementara pada pelatihan pembuatan kerupuk, hasil kerupuknya masih kurang mengembang. Pada proses pengolahan bakso ikan toman dan baung ini, untuk meningkatkan kekenyalan bakso ikan sudah dilakukan dengan penambahan es batu pada saat penggilingan dan penambahan STPP sebanyak $1 \%$ pada adonan. Namun demikian tekstur bakso yang dihasilkan masih kurang kenyal. Hal ini diduga ada hubungannya dengan jenis ikan yang digunakan yang memiliki karakeristik tertentu dan memerlukan konsentrasi STPP yang lebih tinggi. Faktor lainnya adalah terkait dengan suhu adonan masih kurang rendah karena es yang sudah mencair pada saat proses penggilingan. Menurut Duman \& Peksezer (2016), jenis ikan dengan sedikit jaringan ikat dan kadar air yang tinggi akan menghasilkan daging dengan struktur yang lembek. Oleh karena itu masih diperlukan pelatihan berulang secara mandiri dengan menambahkan konsentrasi STPP menjadi $1 \frac{1 / 2}{2} \%$ dan dengan lebih memperhatikan kondisi es batu yang ditambahkan. Sementara itu, kurang mengembangnya kerupuk yang dihasilkan diduga karena kurangnya proses pengadukan atau mungkin dipengaruhi proses penjemuran yang kurang lama, sehingga kerupuk belum benar-benar kering. Oleh karena itu, perlu juga dilakukan pelatihan berulang pengolahan kerupuk ikan toman dan baung secara mandiri untuk memperbaiki kualitas mutu kerupuk yang dihasilkan.

Pada pelatihan tahap II yang berlangsung pada tanggal 27 Juni 2018, mitra PKM mendapatkan pelatihan tentang pengemasan, pelabelan dan perijinan produksi serta manajemen usaha. Proses pengolahan ikan perlu diimbangi dengan pengemasan dari produk olahan ikan yang dihasilkan. Pengemasan bertujuan untuk melindungi produk, penyimpanan, informasi dan promosi produk serta pelayanan kepada konsumen. Pada pelatihan ini diperkenalkan beberapa jenis kemasan dari kertas (termasuk karton), plastik, metal 
seperti aluminium atau stainless steel, komposit (campuran), dan foil berupa lapisan tipis baik dari metal seperti aluminium atau plastik. Untuk produk bakso dan kerupuk, kemasan plastik

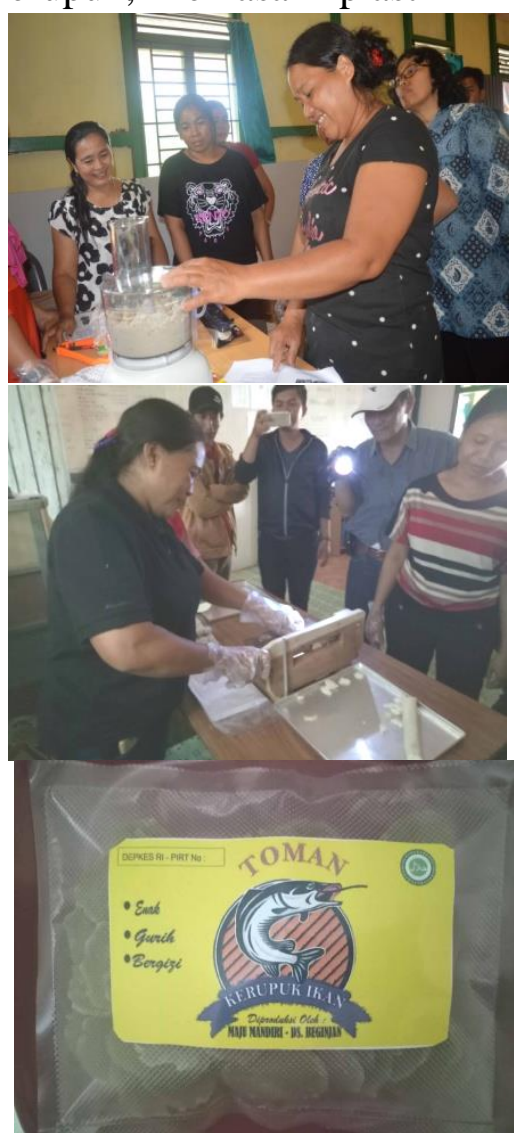

Gambar 4. Pelatihan pengolahan bakso dan kerupuk ikan di Desa Beginjan

Dalam pelatihan tahap II ini juga diberikan materi tentang pelabelan dan perijinan produksi PIRT. Pelabelan adalah informasi yang dapat ditampilkan melalui kemasan. Beberapa informasi yang dapat disampaikan melalui kemasan antara lain adalah: Nama produk, Nama Produsen, Alamat produksi dan telephon yang bisa dihubungi, Komposisi, Kandungan gizi, Cara penggunaan, Kontra indikasi, Tanggal kadaluarsa, Nomer produksi.

Selain materi pasca produksi, mitra PKM juga diberikan materi tentang manajemen usaha.

Materi yang diberikan meliputi aspek penting dalam perencanaan usaha yang terdiri dari aspek pasar dan lebih banyak digunakan karena plastik sifatnya ringan dan kuat serta fleksibel, sehingga mudah dibentuk dalam berbagai ukuran dan bentuk sesuai kebutuhan.

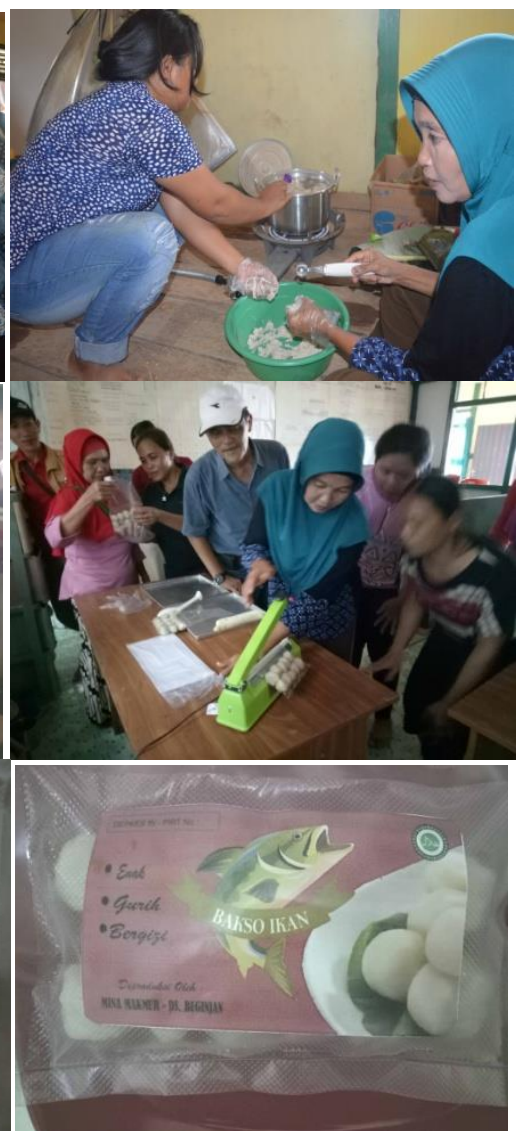

pemasaran, aspek produksi, aspek organisasi dan sumberdaya manusia, aspek legal, aspek finansial. Selain itu juga diberikan materi analisis usaha yang merupakan pemeriksaan keuangan untuk mengetahui sampai di mana keberhasilan yang telah dicapai selama usaha perikanan itu berlangsung. Dengan materi analisis usaha ini, diharapkan mitra PKM dapat membuat perhitungan dan menentukan tindakan untuk memperbaiki dan meningkatkan keuntungan dalam usaha kelompoknya.

Secara keseluruhan, mitra PKM dapat memahami dan mempraktekkan materi berkaitan dengan pengemasan, pelabelan dan perijinan produksi PIRT serta manajemen usaha. Namun 
demikian masih diperlukan pendampingan yang lebih intensif untuk manajemen usaha terkait perencanaan usaha dan pengelolaan keuangan.

\section{Pendampingan, Evaluasi dan Monitoring}

Kegiatan pendampingan bertujuan untuk meningkatkan motivasi mitra untuk mengembangkan usahanya secara komersial dan juga membantu meningkatkan kemampuan ketrampilan mitra dalam pengembangan produk bakso dan kerupuk. Pendampingan tersebut dilakukan dengan mendatangi mitra dan memberi pelatihan kembali berkaitan dengan materi yang kurang dapat dikuasai pada pelatihan sebelumnya dengan harapan mitra PKM dapat lebih siap untuk mengembangkan bakso dan kerupuk ikan secara komersial. Kegiatan pendampingan yang sudah dilakukan menunjukkan adanya dampak positif bagi mitra PKM terlihat dari adanya perbaikan kualitas dari produk bakso dan kerupuk berbahan baku ikan toman dan baung yang dihasilkan. Bakso yang dihasilkan lebih seragam dalam bentuk dan ukuran serta memiliki tekstur yang lebih kenyal, demikian juga kerupuk yang dihasilkan juga lebih mengembang.

Setelah mitra PKM berhasil mengolah kerupuk dan bakso ikan dengan bahan dasar ikan toman dan ikan baung, maka dilakukan uji daya simpan dan uji respon terhadap penampilan dan uji organoleptik dari kedua produk yang akan dipasarkan. Uji daya simpan dilakukan pada produk kerupuk yang sudah dikemas dengan plastik kemas dan dilakukan pengamatan tiap hari untuk ditentukan jumlah hari sampai produk kerupuk tersebut tidak layak konsumsi ( melempem dan tengik). Hasil uji daya simpan kerupuk menunjukkan hasil kerupuk cukup baik yaitu daya simpan selama 25 hari. Daya simpan kerupuk yang cukup baik ini, dikarenakan adanya pengemasan dengan menggunakan sealer dan plastik yang baik, namun tidak terlalu membebani ongkos produksi. Daya simpan yang cukup panjang akan memberikan efek positif pada waktu untuk pemasaran dan menghindari kerugian akibat kerusakan produk, serta dapat memberikan jaminan kualitas produk kerupuk bagi konsumen.

Sementara itu pengujian terhadap penampilan dan organoleptik dilakukan dengan respondennya adalah masyarakat di Desa Beginjan terutama dipilih yang bermata pencaharian di bidang warung makan. Parameter yang diamati terdiri dari kenampakan, bau, rasa dan tekstur produk. Untuk kerupuk, juga dilakukan tambahan karakter uji yaitu kerenyahan. Hasil pengujian menunjukkan bahwa pada kerupuk ikan matang baik toman maupun baung berada pada level baik dengan nilai tertinggi pada karakter rasa. Sementara untuk bakso ikan terdapat perbedaan level kriteria bakso ikan yang dihasilkan yaitu bakso ikan toman pada level sangat baik sedangkan bakso ikan baung pada level baik dengan nilai tertinggi keduanya pada karakter rasa. Hasil tersebut menunjukkan bahwa bakso dan kerupuk ikan berbahan dasar ikan baung dan ikan toman menunjukkan dapat diterima konsumen, sehingga layak untuk dipasarkan. Respon konsumen terhadap produk kerupuk mentah juga cukup baik, sehingga patut dipertimbangkan untuk melakukan penjualan dalam bentuk produk mentah. Namun demikian, perlu dilakukan pengkajian Tentu saja harus dikaji sasaran penjualan yang tepat. Sasaran penjualan untuk produk mentah adalah toko-toko atau kepadarasa orang-orang yang berminat untuk berwirausaha kerupuk dengan membeli produk mentah untuk digoreng dan dipasarkan sendiri. Sehingga dengan demikian dapat menarik perorangan atau kelompok 
masyarakat lain yang belum mandiri untuk berusaha.

Tabel 1. Hasil uji organoleptik terhadap bakso dan kerupuk ikan (matang) yang dihasilkan

\begin{tabular}{lllllll}
\hline $\begin{array}{l}\text { Bahan Baku dan jenis } \\
\text { produk }\end{array}$ & \multicolumn{7}{l}{} \\
\cline { 2 - 7 } & Kenampakan & Bau & Rasa & Tekstur & Rata-rata & Kriteria \\
\hline Bakso ikan baung & 7.9 & 7.5 & 8.4 & 7.4 & 7.8 & Baik \\
Bakso ikan toman & 7.9 & 8.2 & 8.6 & 7.8 & 8.1 & Sangat baik \\
Kerupuk ikan baung & 7.8 & 7.8 & 8.2 & 7.8 & 7.9 & Baik \\
Kerupuk ikan toman & 7.4 & 7.7 & 8.2 & 7.6 & 7.7 & Baik \\
& & & & & & \\
\hline
\end{tabular}

\section{Dampak Kegiatan Pengabdian dan Kesulitan Pelaksanaan}

Berdasarkan hasil pengamatan di lokasi usaha mitra PKM, dampak dari pelaksanaan pelatihan pengolahan bakso dan kerupuk ikan berbahan baku ikan toman dan baung, yang diikuti dengan pendampingan penggunaan teknologi pengolahan ikan sudah menunjukkan dampak positif terhadap usaha mitra. Mitra PKM sudah mengembangkan kedua produk untuk keperluan sendiri dan sebagian dijual pada skala lokal yaitu untuk masyarakat sekitar. Hal ini disebabkan belum adanya kepercayaan diri untuk memproduksi dan memasarkan produk bakso ikan dan kerupuk ikan yang merupakan produk baru di kawasan Desa Beginjan. Selama ini mereka hanya mengenal bakso daging sapi atau bakso ikan tengiri yang banyak di jual di pasaran. Untuk itu, perlu diupayakan pengenalan produk ke masyarakat yang lebih luas yang dapat dilakukan melalui berbagai kegiatan seperti pameran ataupun pada kegiatan perayaan hari besar. Kesulitan dalam pelaksanaan PKM ini adalah terkait dengan jarak yang jauh antara lokasi pengabdian dan lokasi domisili tim pelaksana yaitu sekitar 2,5 jam, sehingga pendampingan dan monitoring tidak bisa dilakukan lebih intensif.

\section{SIMPULAN}

Beberapa kesimpulan yang dapat diambil dari kegiatan PKM ini adalah:

1. Kegiatan PKM ini mendapat respon yang baik dari mitra PKM terbukti dengan keterlibatan mitra secara aktif serta peningkatan ketrampilan mitra dalam pelaksanaan diversifikasi olahan ikan.

2. Mitra PKM dapat mempraktekkan pengolahan produk kerupuk dan bakso ikan dengan baik dan memasarkannya dalam lingkup skala local.

Rekomendasi untuk kegiatan pengabdian kepada masyarakat berikutnya adalah perluasan jangka pemasaran melalui pemasaran on line.

\section{UCAPAN TERIMA KASIH}

Ucapan terima kasih yang setinggi-tingginya kepada Direktorat Riset dan Pengabdian MasyarakatDIKTI atas hibah Program Kemitraan Masyarakat sehingga dapat terlaksana kegiatan ini.

\section{DAFTAR PUSTAKA}

Bekitz H.D, G Werner, P. Schieberle. (2009). Food Chemistry. 4th. Springer Berin.Berlin 
Ernawati A.T.D, A.Wulandari. (2013).

Uji Kimia Keripik Kulit Ikan patin (Pangasius pangasius) dengan Perbedaan Perlakuan Suhu Perendaman. Magistra Th XXV No. 83

Duman, Nuhsine, and Busra Peksezer. (2016). Quality changes of fish balls prepared from of mosul bleak (Alburnus mossulensis) stored at $18{ }^{\circ} \mathrm{C}$ under air or vacuum. Ege Journal of Fisheries Aquatic Sciences, 33(3):285-290.

Hariohoedojo A., H. Minantyo, P.S. Winarno. (2015). The Creation of Barracuda Fish Based Meatball as Nutritious Food. Food Science and Quality Management. 43: 73-79.

Laiya, N., R.M. Harmain, N. Yusuf, (2014). Formulasi Kerupuk Ikan Gabus yang Disubstitusi dengan Tepung Sagu. Jurnal Ilmiah Perikanan dan Kelautan. Vol. II (2): 81-87

Nurhuda HS, Junianto, E. Rochima. (2017). Penambahan Tepung Karaginan Terhadap Tingkat Kesukaan Bakso Ikan Manyung. Jurnal Perikanan dan Kelautan. Vol. VIII (1):1:157-164

Purnomo, H., D. Rahardian. (2008). Review Article: Indonesian Traditional Meatball.
International Food Research Journal 15(2): 101-108

Purnomo, J. S. (2014). Diversifikasi Olahan Berbasis Ikan Patin di Desa Jingah Habang Hilir Kecamatan Karang Intan Kabupaten Banjar Kalimantan Selatan. Fish Scientiae, Vol. 4 (8): 80-80.

Poernomo D., Sugeng. H. S., Bayu. P. S. (2013). Karakteristik Fisika Kimia Bakso dari Daging Lumat Ikan Layaran (Istiophorus Orientalis). JPHPI, Vol. 16 (1)

Riyadi N.H, W. Atmaka. (2010). Diversifikasi dan Karakterisasi Citarasa Bakso Ikan tenggiri (Scomberomus commerson) dengan Penambahan Asap Cair Tempurung Kelapa. Jurnal Teknologi Hasil Pertanian, Vol. III (1): 1-12

Setiawan. D.W., T.D. Sulityati, E. Suprayitno. (2013). Pemanfaatan Residu Daging Ikan Gabus (Ophiocephalus striatus) dalam Pembuatan Kerupuk Ikan Beralbumin. THPi Student Journal Universias Brawijaya. Vol. I (1) :21 -32.

Wardhani, R.M, Indah R.P, Indayati. (2010). Peningkatan Pendapatan Masyarakat Melalui Diversifikasi Produk Olahan Ikan. Agritek. Vol 11 (2): 54-63. 